\title{
Supply Demand Ratio and Water Utilization Index in Jurala Project Command Area, Andhra Pradesh, India
}

\author{
T. L. Neelima ${ }^{1^{*}}$, K. V. Ramana ${ }^{2}$, M. Devender Reddy ${ }^{3}$, M. Uma Devi ${ }^{4}$, V. Ramulu ${ }^{5}$ and A. V. Ramanjaneyulu ${ }^{6}$ \\ ${ }^{1}$ Agricultural Polytechnic, Palem, Mahabubnagar district, Andhra Pradesh (509 215), India \\ ${ }^{2}$ National Remote Sensing Center (NRSC), Balanagar, Hyderabad, Andhra Pradesh (500 042), India \\ ${ }^{3,4,5}$ Water Technology Centre, ANGRAU, Rajendranagar, Hyderabad, Andhra Pradesh (500 030), India \\ ${ }^{6}$ Regional Agricultural Research Station, Palem, ANGRAU, Mahabubnagar district, Andhra Pradesh (509 215), India
}

\section{Article History}

Manuscript No. cn368

Received in $10^{\text {th }}$ February, 2013

Received in revised form $8^{\text {th }}$ January, 2014

Accepted in final form $28^{\text {th }}$ February, 2014

\section{Correspondence to}

"E-mail: t_1_neelima@yahoo.co.in

\section{Keywords}

Performance indicators, supply demand ratio, water utilization index

\begin{abstract}
The Priyadarsini Jurala Project (PJP) is a multipurpose project constructed across the river Krishna, near Revulapalli village, mainly designed to irrigate low water requirement crops in the drought prone area of Mahabubnagar district, Andhra Pradesh. The irrigation performance assessment of any project is judged using performance indicators. Hence, the performance indicators namely supply demand ratio and water utilization index (WUI) were calculated, which will help to know whether water supplied is based on timely crop irrigation demand and also if the irrigation performance is appropriate at all the reaches in the command area. Crop area was monitored using two years remotely sensed (RS) data of IRS P6 LISS-III and AWiFs sensor. The principal crop grown in the command area during kharif season was paddy ( $0.0234 \mathrm{mha})$, of which $37.2 \%$ of the area was under right canal and $62.8 \%$ was under left canal. The monthly net irrigation requirement (NIR) of remote sensing derived cropping pattern was calculated for RMC and LMC using CROPWAT model. The calculated monthly supply-demand ratio showed that the irrigation supply was more than demand. The WUI was low for left canal as compared to the right canal.
\end{abstract}

\section{Introduction}

India has one of the largest and most ambitious irrigation programme in the world with net irrigated area exceeding 47 mha. The land under irrigation has expanded from $22.6 \mathrm{mha}$ in 1950 to 90 mha in 2000, with $52 \%$ being irrigated by surface water through canal network (Planning commission, 2007). Unfortunately, the overall efficiency of the canal irrigation system is very low which leads to poor utilization of the irrigation potential created at huge cost. The average overall project efficiency of several canal irrigation projects in the rice growing areas in the world has been estimated to be $23 \%$ and that of non-paddy crops to be $40 \%$. Bos and Nugteren (1990) from International Institute of Reclamation and Improvement (ILRI), Netherlands reviewed the conveyance losses in irrigation supply schemes of different countries of the world and reported maximum conveyance loss of $60 \%$ in India and minimum in Philippines (13\%). Sanmuganathan and Bolton (1988) reported that the canal irrigation efficiency in India is only $30-35 \%$. It is because of the fact that India most of the irrigation networks are unlined and huge amount of irrigation water is lost in main canal, distributor, minors and field channels. Navalwala (1991) found that about $71 \%$ of the irrigation water is lost in the whole process of its conveyance from head works and application in the field. The breakup of the losses are main and branch canal (15\%), distributaries (7\%), water courses $(22 \%)$ and field losses $(27 \%)$. This leads to not only poor utilization of irrigation potential created at huge cost, but also aggravates the degradation of soil and water resources and thereby endangers the sustainability of agricultural production system (Ramesh et al., 2010). As the cost of creating additional irrigation potential in terms of financial, human and environmental aspects has increased tremendously, need of the hour is to increase the irrigation efficiency of existing projects and use saved water for irrigating new areas.

The Priyadarsini Jurula Project (PJP) is mainly designed to cultivate irrigated dry crops in the drought prone mandals of Mahabubnagar district, Andhra Pradesh, India in an area of 0.143 mha under RMC (Right main canal) and 0.0325 
mha under LMC (Left main canal). However, the farmers are growing paddy to a large extent in the command area due to which the system is suffering from excess water utilization in the head reach distributaries leading to inadequate supply and poor availability of water in the tail reach distributaries. Therefore keeping in view the need to increase the irrigation efficiency of the existing projects and reduce the gap between potential and actual area, Irrigation performance assessment of Jurala project was taken up to realize the actual water supply and demand ratio and the water utilization index in the command area.

\section{Materials and Methods}

\subsection{Study area}

The Priyadarshini Jurala Project (PJP) is a multipurpose project constructed across the river Krishna, near Revulapally village in Mahabubnagar district of Andhra Pradesh, India. The district is the second largest in Andhra Pradesh, spreading over a total geographical area of $18,432 \mathrm{~km}^{2}$ and divided into 64 mandals.

\subsection{Edapho-climatic conditions}

Soils of the study area varied from sandy loam to sandy clay loam with $\mathrm{pH}$ and $\mathrm{EC}$ ranging from 4.56 to 8.84 and 0.10 to $2.56 \mathrm{dS} \mathrm{m}^{-1}$ respectively. The water holding capacity of the soils at field capacity was $12 \%$ for sandy loam and $40 \%$ for sandy clay loam soils. The soils are low in available nitrogen $\left(<280 \mathrm{~kg} \mathrm{~N} \mathrm{ha}^{-1}\right)$, medium in available phosphorus (22 to 280 $\mathrm{kg} \mathrm{P}_{2} \mathrm{O}_{5} \mathrm{ha}^{-1}$ ) and low to high in available potassium content ( 78 to $378 \mathrm{~kg} \mathrm{~K}_{2} \mathrm{O} \mathrm{ha}^{-1}$ ). Climate of the study area is semi-arid with distinct summer, winter and rainy seasons. More than $75 \%$ rainfall is received through south west monsoon in this area.

\subsection{Weather data and analysis}

The study area falls under five mandals, hence, weather data was taken from Automatic weather station (AWS) located in the respective mandal head quarters, for analysis. The Automatic weather station (AWS) data for hourly basis during the crop growth period was procured from APSRSAC (Andhra Pradesh State Remote Sensing Application Centre) and processed in MS Access to obtain data on daily basis. The total rainfall during the crop growth period (June to November) i.e., kharif 2009 was $862.6 \mathrm{~mm}$ (29 rainy days) in Gadwal mandal and $886.4 \mathrm{~mm}$ (22 rainy days) in Itikyal mandal of RMC (Table 1a). While in Atmakur, Pebbair and Weepanagandla of LMC, the seasonal rainfall was $830.4 \mathrm{~mm}$ (25 rainy days), $877.0 \mathrm{~mm}$ (26 rainy days) and $362.1 \mathrm{~mm}$ (23 rainy days), respectively (Table 1b). During kharif 2010, the total seasonal rainfall was $811.8 \mathrm{~mm}$ (46 rainy days) in Gadwal mandal and $709.4 \mathrm{~mm}$ (40 rainy days) in Itikyal mandal of RMC.

In case of Atmakur, Pebbair and Weepanagandla mandals of LMC, the seasonal rainfall was $1167.0 \mathrm{~mm}$ (43 rainy days), $832.0 \mathrm{~mm}$ (36 rainy days) and $406.8 \mathrm{~mm}$ (29 rainy days), respectively. The distribution of rainfall was also erratic in the study area. Very low rainfall was received in July month during 2009, however, good amount of rainfall was received in 2010. Further, around $300 \mathrm{~mm}$ rainfall was received in a span of three days during October 2009 in all mandals except Weepanagandla (174.8 $\mathrm{mm}$ in three days) of the study area. During kharif 2009, crop suffered due to low and uneven distributed rainfall. On the other hand, high rainfall with more humidity resulted in outbreak of pest (brown plant hopper) and disease (blast) incidence during kharif 2010.

\subsection{Selection of representative distributaries}

After preliminary survey of the command area, one representative distributory each from head, middle and tail reaches of both the right $(50 \mathrm{~m}$ length) and left (100 m length) main canals were selected located in five mandals viz., Atmakur, Gadwal, Itikyal, Pebbair and Weepanagandla.

2.5. Estimation of crop area, crop water demand and performance indicators

\begin{tabular}{|c|c|c|c|c|c|c|c|c|}
\hline \multirow[t]{3}{*}{ Month } & \multicolumn{4}{|c|}{ Gadwal } & \multicolumn{4}{|c|}{ Itikyal } \\
\hline & \multicolumn{2}{|c|}{$\overline{2009}$} & \multicolumn{2}{|c|}{2010} & \multicolumn{2}{|c|}{2009} & \multicolumn{2}{|c|}{2010} \\
\hline & $\overline{T R}$ & $\mathrm{Pe}$ & $\overline{\mathrm{TR}}$ & $\mathrm{Pe}$ & TR & $\mathrm{Pe}$ & TR & $\mathrm{Pe}$ \\
\hline June & 135 & 105.6 & 73.8 & 54.2 & 155.0 & 115.7 & 54.2 & 42.5 \\
\hline July & 10 & 9.8 & 263 & 123.2 & 14.6 & 14.0 & 215.0 & 116.2 \\
\hline August & 39.4 & 33.2 & 244.8 & 107.4 & 84.4 & 57.0 & 273.8 & 107.5 \\
\hline September & 281.2 & 138.6 & 118 & 86.7 & 230.4 & 106.4 & 51.8 & 44.3 \\
\hline October & 312.2 & 72.9 & 55.2 & 47.4 & 307.4 & 72.4 & 79.4 & 56.9 \\
\hline November & 80.2 & 51.3 & 54.6 & 46.5 & 94.6 & 53.8 & 27.6 & 25.7 \\
\hline December & 4.6 & 4.5 & 2.4 & 2.4 & 0.0 & 0.0 & 7.6 & 7.3 \\
\hline Total & 862.6 & 415.9 & 811.8 & 467.8 & 886.4 & 419.3 & 709.4 & 400.4 \\
\hline
\end{tabular}

TR: Total rainfall $(\mathrm{mm})$; Pe: Effective rainfall $\left(\mathrm{mm} \mathrm{day}^{-1}\right)$ 


\begin{tabular}{|c|c|c|c|c|c|c|c|c|c|c|c|c|}
\hline \multirow{3}{*}{ Month } & \multicolumn{4}{|c|}{ Atmakur } & \multicolumn{4}{|c|}{ Pebbair } & \multicolumn{4}{|c|}{ Veepangandla } \\
\hline & \multicolumn{2}{|c|}{2009} & \multicolumn{2}{|c|}{2010} & \multicolumn{2}{|c|}{2009} & \multicolumn{2}{|c|}{2010} & \multicolumn{2}{|c|}{2009} & \multicolumn{2}{|c|}{2010} \\
\hline & TR & $\mathrm{Pe}$ & TR & $\mathrm{Pe}$ & TR & $\mathrm{Pe}$ & TR & $\mathrm{Pe}$ & TR & $\mathrm{Pe}$ & TR & $\mathrm{Pe}$ \\
\hline June & 106.6 & 83.2 & 194.0 & 75.7 & 72.0 & 62.3 & 46.0 & 35.8 & 44.0 & 39.4 & 20.8 & 19.1 \\
\hline July & 0.0 & 0.0 & 555.0 & 180.5 & 40.0 & 34.0 & 221.0 & 83.1 & 15.1 & 14.6 & 164.6 & 86.6 \\
\hline August & 72.0 & 57.4 & 181.0 & 105.0 & 89.0 & 63.2 & 331.2 & 118.2 & 39.4 & 35.2 & 105.0 & 64.1 \\
\hline September & 258.8 & 130.9 & 117.0 & 81.0 & 230.0 & 108.1 & 128.6 & 92.1 & 84.2 & 69.4 & 93.2 & 73.4 \\
\hline October & 361.0 & 77.8 & 65.0 & 47.6 & 399.0 & 81.6 & 95.6 & 79.1 & 174.8 & 59.1 & 2.2 & 2.2 \\
\hline November & 32.0 & 29.3 & 55.0 & 40.5 & 47.0 & 37.3 & 9.6 & 9.2 & 4.6 & 4.5 & 18.4 & 16.8 \\
\hline December & 0.0 & 0.0 & 0.0 & 0.0 & 0.0 & 0.0 & 0.0 & 0.0 & 0.0 & 0.0 & 2.6 & 0.0 \\
\hline Total & 830.4 & 378.6 & 1167.0 & 530.3 & 877.0 & 386.5 & 832.0 & 417.5 & 362.1 & 222.2 & 406.8 & 262.2 \\
\hline
\end{tabular}

TR: Total rainfall (mm); Pe: Effective rainfall $\left(\mathrm{mm} \mathrm{day}^{-1}\right)$

The crop area in the command area was estimated with the help of ERDAS IMAGINE 10 image analysis software using maximum likelihood algorithm. Crop water demand on monthly basis was estimated using CROPWAT model to predict the water requirement of the command area and thus the monthly supply-demand ratio was computed to study its impact on crop productivity (Chandra Mouli and Panda, 2008). Water utilization index is estimated using satellite derived irrigated cropped area and command discharges (Rao, 1993).

\section{Results and Discussion}

\subsection{Crop area estimates}

Crop area was monitored using two years remotely sensed data of IRS P6 LISS-III and AWiFs sensor. The cloud free images taken from LISS-III sensor on $14^{\text {th }}$ October and $2^{\text {nd }}$ November during kharif 2009 and the images taken from AWiFs sensor on $28^{\text {th }}$ October during the year 2010, were used to extract crop area information. The principal crop grown in the command area during kharif season was paddy (wet crop). Out of the total rice area cultivated in the command area (0.0234 mha), $37.2 \%$ of the area was under right canal and $62.8 \%$ was under left canal. While, orchards occupied very little area (0.0049 $\mathrm{mha}$ ) and groundnut was cultivated during rabi season in kharif fallows (0.00322 mha). The maximum likelihood (MXL) algorithm was used to delineate different crop classes in the ERDAS Imagine 10, image analysis software.

The total irrigated cropped area in right and left main canal of Jurala command was 0.012 mha and 0.019 mha during the kharif 2009 and 0.012 mha and 0.021 mha during kharif 2010. The total cropped area has increased by 2046.8 ha during 2010 as compared to 2009 . At the same time, there was an increase in the paddy area from 0.023 mha to 0.027 mha and consequently there was decline in the other crops area from 3217.1 to 1957.7 ha during 2010 . Out of the total irrigated area, paddy area increased from 70.7 to $72.4 \%$ under the right main canal and from 76.3 to $83.5 \%$ under the left main canal of Jurala project command (Table 2). A significant increase in the paddy area during kharif 2010 might be due to receipt of good amount of rainfall starting from June month. However, during 2009, due to low rainfall and drought at initial stages, most of the farmers did not grow paddy during kharif but have gone for irrigated dry (ID) crops like groundnut in rabi after receiving heavy rains during October 2009. Added to this, floods during October 2009 also washed away the rice crop in some pockets.

During kharif 2010, as the cloud free data of LISS III sensor was not available and identification of orchards was difficult and so with the use of medium resolution data $\left(56 \times 56 \mathrm{~m}^{2}\right)$ for analysis, only paddy crop and other crop classes were extracted from the AWiFs sensor in the year 2010. The area under orchards in the field conditions was less than one hectare area. Hence, the orchard mask extracted using LISS-III image $\left(24 \times 24 \mathrm{~m}^{2}\right)$ during the year 2009 was utilized for the year 2010.

The distributary command wise crop area, for selected six distributaries, showed that rice is the main crop in all these distributaries and there was a general increase in the rice area during kharif 2010 as compared to that of 2009 . The area under Orchards and other crops like rabi groundnut increased towards the tail reach of the right (D-34) and left (D-23) main canal of the command area (Table 3 ) than head reach distributaries. The classification accuracy estimated using LISS III and AWiFs sensors of IRS P6 satellite during kharif 2009 and 2010 was 92 and $90 \%$, respectively (Table 4). Similar results were reported by Monserud and Leeman (1992).

\subsection{Supply-demand ratio}

Rice variety of 140 days duration (BPT 5204) was cultivated in the command area. The critical crop growth period of rice is falling within 45 to 65 days from the date of transplanting, 
which coincided with September to October months. Hence, assessment of irrigation water supply and crop demand gap in the entire crop growth period and more particularly during critical growth stage is a driving parameter to regulate crop productivity (Chandra Mouli and Panda, 2008).

Using CROPWAT model, monthly net irrigation requirement (NIR) of remote sensing (RS) derived cropping pattern

Table 2: Crop area (ha) statistics extracted from the satellite image for PJP right and left main canal during kharif 2009 and 2010

\begin{tabular}{lcccccc}
\hline Crop & \multicolumn{3}{c}{2009} & \multicolumn{3}{c}{2010} \\
\cline { 2 - 7 } & RMC & LMC & Total & RMC & LMC & Total \\
\hline Paddy & 8695 & 14704 & 23399 & 8785 & 17920 & 26705 \\
$\begin{array}{l}\text { Other crop } \\
\text { (Groundnut) }\end{array}$ & 1206 & 2010 & 3217 & 964 & 993 & 1957 \\
$\begin{array}{l}\text { Orchard } \\
\begin{array}{l}\text { Total irri- } \\
\text { gated area }\end{array}\end{array}$ & 2388 & 2548 & 4937 & 2388 & 2548 & 4937 \\
\hline
\end{tabular}

Table 3: Crop area (ha) statistics extracted from the satellite image for six selected distributaries of Jurala command area during kharif 2009 and 2010

\begin{tabular}{lccccc}
\hline Reaches and & \multicolumn{2}{c}{ Rice } & \multicolumn{2}{c}{ Other crops } & Orchard \\
\cline { 2 - 4 } distributary no. & 2009 & 2010 & 2009 & 2010 & $2009 / 2010$ \\
\hline & \multicolumn{5}{c}{ Right main canal } \\
Head reach $\left(\mathrm{D}_{4 \mathrm{~b}}\right)$ & 97.3 & 103.3 & 8.2 & 5.7 & 12.6 \\
Middle reach $\left(5_{\mathrm{L}}\right)$ & 241.2 & 246.8 & 57.7 & 16.1 & 115.1 \\
Tail reach $\left(\mathrm{D}_{34}\right)$ & 1298.6 & 1416.9 & 82.1 & 146.6 & 478.5 \\
\cline { 2 - 4 } & Left main canal & & \\
Head reach $\left(\mathrm{D}_{5}\right)$ & 61.1 & 61.8 & 13.6 & 8.1 & 18.4 \\
Middle reach & 2760.0 & 3054.9 & 114.8 & 105.4 & 95.7 \\
(RLMC) & 461.5 & 468.7 & 82.5 & 28.1 & 294.3 \\
Tail reach $\left(\mathrm{D}_{23}\right)$ & & & &
\end{tabular}

Table 4: Classification accuracy of various land cover classes generated for $2^{\text {nd }}$ November 2009 and $14^{\text {th }}$ October 2009 classified image

\begin{tabular}{lcccc}
\hline Class & \multicolumn{2}{c}{2009} & \multicolumn{2}{c}{2010} \\
\cline { 2 - 5 } & PA & UA & PA & UA \\
\hline Rice & 96 & 93 & 96 & 89 \\
Other crops & 100 & 89 & 81 & 89 \\
Barren land & 93 & 89 & - & - \\
Sand/fallow & 83 & 89 & - & - \\
Build up area & 96 & 89 & - & - \\
Shrub & 81 & 93 & - & - \\
Orchard & 90 & 93 & 94 & 86 \\
Water body & 100 & 100 & 100 & 100 \\
\hline
\end{tabular}

PA: Producers accuracy (\%); UA: Users accuracy (\%) was calculated. The gross irrigation requirement (GIR) was estimated by considering $70 \%$ irrigation system efficiency (Gaur et al., 2008). The monthly crop irrigation demand and corresponding canal supplies for right and left main canal during kharif 2009 and 2010 were obtained from Jurala camp office located at Gadwal, Mahabubnagar dist, Andhra Pradesh. In comparison to irrigation water demand, excess canal supply was noticed during all the months of crop growth period of rice, in right and left main canal during both the years of study. Therefore, it is imperative to supply the irrigation water based on timely crop irrigation demand in the command area. The supply-demand ratio was high during September month for both the study years. The average supply-demand ratio was found to be higher (4.34 and 5.89) during 2009 than that of 2010 (2.64 and 5.21) for PJP right and left main canal, respectively as shown in Table 5.

\subsection{Water utilization index (WUI)}

Water utilization index (WUI) or duty of water is defined as area irrigated per unit volume of water which is a measure of water delivery performance. It is one of the important spatial performance indicators of an irrigation system. In broader sense, this is a measure of effective utilization of water in an irrigation command area and it enables to compare the performance of irrigation system across the command i.e., at disaggregated level. In most of the irrigation systems, the system manager distributes the water to the canals according to the water duty specified. Water duty is the number of acres of land irrigated per cubic feet per second (cusec) of water in a crop season. Water duty does not vary with time. It gives an approximate estimation of water required for a crop over a gross period like a season. Typically, duties of 4000 ha $\mathrm{TMC}^{-1}$ and 8000 ha TMC $^{-1}$ are adopted for a wet crop like rice and dry crop like groundnut, respectively. WUI is estimated based on the equivalent wet area and amount of water released in to the various irrigation units.

The water drawls were high (5.6 and 11.08 TMC) during 2009 for PJP right and left main canal compared to 4.23 and 8.7 TMC in 2010 for right and left main canals, respectively. The WUI was low for left canal (1577.4 and 2319.4 ha $\mathrm{TMC}^{-1}$ ) as compared to the right canal (1971.1 and 2571.5 ha $\mathrm{TMC}^{-1}$ ) during kharif 2009 and 2010. The WUI estimated for six selected distributaries under right and left main canal of Jurala command area during kharif 2009 and 2010 is presented in Table 6 .

In the right main canal, there was decrease in WUI from head reach distributary to tail reach during both the years of study. However, in the left main canal, the WUI was high for the middle reach distributary followed by head and tail reaches. The WUI at disaggregate levels indicate that the irrigation 


\begin{tabular}{lcccc}
\hline $\begin{array}{l}\text { Table 5: } \\
\text { canal during kharif 2009 and 2010 }\end{array}$ & $\begin{array}{c}\text { Supply-demand ratio for PJP right and left main } \\
\text { Month }\end{array}$ & \multicolumn{2}{c}{$\begin{array}{c}\text { Right main canal } \\
\text { (RMC) }\end{array}$} & \multicolumn{2}{c}{$\begin{array}{c}\text { Left main canal } \\
\text { (LMC) }\end{array}$} \\
\cline { 2 - 5 } & 2009 & 2010 & 2009 & 2010 \\
\hline Jul & 0.5 & 0.4 & 1.1 & 0.7 \\
Aug & 1.2 & 0.9 & 2.4 & 1.6 \\
Sep & 13.1 & 4.4 & 14.0 & 11.9 \\
Oct & 3.2 & 3.5 & 6.2 & 6.6 \\
Nov & 3.7 & 4.0 & 5.8 & 5.2 \\
Average & 4.34 & 2.64 & 5.89 & 5.21 \\
\hline
\end{tabular}

Table 6: Water utilization index (WUI) for the selected distributaries and for the entire right and left main canal under Jurala irrigation command area (kharif 2009 and 2010)

\begin{tabular}{|c|c|c|c|c|c|c|}
\hline \multirow{2}{*}{$\begin{array}{l}\text { Distributary } \\
\text { no. }\end{array}$} & \multicolumn{3}{|c|}{ WUI (ha $\mathrm{mm}^{-3}$ ) } & \multicolumn{3}{|c|}{ WUI (ha TMC-1) } \\
\hline & 2009 & 2010 & Avg. & 2009 & 2010 & Avg. \\
\hline & \multicolumn{4}{|c|}{ Right main canal } & & \\
\hline $\begin{array}{l}\text { Head reach } \\
\left(D_{4 b}\right)\end{array}$ & $\overline{80.2}$ & 111.6 & 95.9 & 2271.3 & 3160.5 & 2715.9 \\
\hline $\begin{array}{l}\text { Middle reach } \\
\left(5_{L}\right)\end{array}$ & 74.8 & 96.0 & 85.4 & 2118.3 & 2718.7 & 2418.5 \\
\hline $\begin{array}{l}\text { Tail reach } \\
\left(D_{34}\right)\end{array}$ & 58.2 & 80.3 & 69.3 & 1648.2 & 2274.1 & 1962.6 \\
\hline \multirow[t]{2}{*}{ Entire RMC } & 69.6 & 90.8 & 80.2 & 1971.1 & 2571.5 & 2271.3 \\
\hline & \multicolumn{4}{|c|}{ Left main canal } & & \\
\hline $\begin{array}{l}\text { Head reach } \\
\left(D_{5}\right)\end{array}$ & 41.0 & 48.4 & 44.7 & 1161.1 & 1370.7 & 1265.9 \\
\hline $\begin{array}{l}\text { Middle reach } \\
\text { (RLMC) }\end{array}$ & 51.3 & 71.6 & 61.4 & 1452.8 & 2027.7 & 1738.8 \\
\hline $\begin{array}{l}\text { Tail reach } \\
\left(D_{23}\right)\end{array}$ & 37.7 & 48.5 & 43.1 & 1067.7 & 1373.5 & 1220.6 \\
\hline Entire LMC & 55.7 & 81.9 & 68.8 & 1577.4 & 2319.4 & 1948.4 \\
\hline
\end{tabular}

ha $\mathrm{mm}^{3}$ : hectare million cubic meter

units with higher Cultural Command Area have registered lower levels of WUI. Chakraborthi et al. (2001) reported that in Nagarjunasagar Left Bank Irrigation Command in Andhra Pradesh during 1990-91, area irrigated was much less per unit of canal irrigation water supplied ( 65 ha irrigated million $\mathrm{m}^{-3}$ water supplied), compared to 1998-99, when better utilization of canal irrigation water was achieved ( 92 ha irrigated million $\mathrm{m}^{-3}$ water supplied).

\section{Conclusion}

The area estimated was nearer to estimates of the revenue department. The performance indicators showed that only $50 \%$ of the command area under PJP is irrigated during both the years indicating very low project water efficiency. The temporal and spatial variations of such indicators can describe performance of irrigation schemes in different dimensions for the benefit of decision makers. The government can take measures to improve the project water use efficiency by extending the irrigation water to larger areas under project command. Further, such studies periodically will improve the efficiency of irrigation projects in Andhra Pradesh and elsewhere in the country.

\section{Acknowledgements}

The authors are grateful to ICAR, New Delhi, India for providing the financial assistance under Niche Area of excellence programme on Capacity building and research on improving agricultural water productivity.

\section{References}

Bos, M.G., Nugteren, J., 1990. On Irrigation Efficiencies, $4^{\text {th }}$ edn. ILRI Publication 19. International Institute for Land Reclamation and Improvement, Wageningen, Netherlands, 138.

Chakraborthi, A.K., Rao, V.V., Shanker, M., Suresh Babu, A.V., 2001. Performance evaluation of an irrigation project using satellite Remote Sensing, GIS and GPS Water Resources Group, NRSA. Project Report, February 2001, 168.

Chandra Mouli, G., Panda, S.N., 2008. Mapping the Features of an Irrigation Project for Performance Assessment, 4. Available from http://www.gisdevelopment. net/application/agriculture/ irrigation/ mwf09 gchandramouli.html.

Gaur, A., Biggs, T.W., Gumma, M.K., Parthasaradhi, G., Turral, H., 2008. Water scarcity effects on equitable water distribution and land use in a major irrigation projectCase study in India. Journal of Irrigation and Drainage Engineering 132(3), 26-34.

Monserud, R.A., Leemans, R., 1992. Comparing global vegetation maps with the Kappa statistic. Ecological Modelling 62, 275-293.

Navalwala, B.N., 1991. Waterlogging and its related issues in India. Journal of Irrigation and Power 1, 55-64.

Planning Commission, 2007. Report of the steering committee of Agriculture for the eleventh five year plan (20072012), Government of India, New Delhi, 20.

Ramesh C.S., Sheelabhadra, M., Ramlal, B., Singanduppe, R.K., Mohanty, Madhu, S.B., Lala, I.P. Ray., Deepika, S., 2010. Feasibility evaluation of pressurized irrigation in canal commands. Water Resource Management 24, 
3017-3032.

Rao, P.S., 1993. Review of selected literature on indicators of irrigation performance. IIMI Research Paper No. 13. Colombo, Sri Lanka, International Management Institute, Colombo, Sri Lanka, 1-75.
Sanmuganathan, K., Bolton, P., 1988. Water management in third world irrigation schemes- lesson from the field. ODU Bulletin 11, Hydraulic Research, London, UK, 4. 